Journal of Development and Communication Studies, Vol. 8. No. 2, July-December, 2021 ISSN (Online \& Print): 2305-7432. http://www.devcomsjournalmw.org

\title{
Food Security Communication: An Investigation into the Influence of Radio Programmes on Irish Potato Farming in Nakuru County, Kenya
}

Hillary Sang, Kenya Water Towers Agency, Email: hkasang@gmail.com, Mary Mogute Department of Development Studies, Daystar University, Kenya, \& Leah Komen, Director of Research and Postgraduate Studies, School of Communication, Daystar University, Kenya.

\begin{abstract}
The Government of Keny a recognizes Irish potato as one of the food security and nutrition crops together with maize and rice (GoK, 2017). This study sought to investigate the influence of radio programmes in promoting Irish potato farming as a contributor to food security in Nakuru County. The study looked at the period between 2012 and 2015 when most radio stations started programmes on agriculture. Purposive sampling method was used to identify four sub-counties in Nakuru County namely: Kuresoi South, Kuresoi North, Molo and Naivasha. A census of forty-eight farmers registered with the National Potato Council of Kenya between 2012 and 2015 were interviewed. Eleven agricultural extension officers from the sampled sub-counties were interviewed as key informants. The study established that Irish potato farmers listened and applied skills acquired from agricultural radio programmes to improve their farming leading to food security in Nakuru County. Information inaccuracy was revealed as one of the challenges during the study. Radio should, therefore, provide accurate information on specific varieties for specific regions so that Irish potato farming flourishes and nourishes Nakuru people.
\end{abstract}

Key words: Radio, Irish potato, Food security, Communication, and Nakuru County

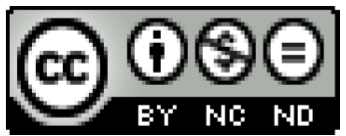

(C) 2021. The authors. This work is licensed under the Creative Commons Attribution 4.0 International License (CC-By-NC-ND). Users may freely share and redistribute this work provided that the author and the Journal of Development and Communication Studies are fully acknowledged. Users may not tweak or remix and offer this work for sale. The full license may be accessed at https://creativecommons.org/licenses/by-nc-nd/4.0/

To cite this article: Sang, H., Mogute, M., \& Komen, L. (2021), Food Security Communication: An Investigation into the Influence of Radio Programmes on Irish Potato Farming in Nakuru County, Kenya, Journal of Development and Communication Studies, 8(2) https://dx.doi.org/10.4314/jdcs.v8i2.7

\section{Introduction}

Food security is still a serious global scourge affecting many countries and needs drastic measures to curb it. According to Godfray et al. (2010), a threefold challenge is now facing the world and this can be addressed by matching the rapidly changing demand for food to a steady supply that is environmentally and socially sustainable; and that ensures that the world's poorest people are no longer hungry. This challenge requires changes in the way food is produced, stored, processed, distributed, and accessed that are as radical as those that occurred during the $18^{\text {th }}$ and $19^{\text {th }}$ Century Industrial and Agricultural Revolutions and the 20th-century Green Revolution (Godfray et al., 2010).

To achieve these goals, food security communication should be reengineered to ensure free flow of information to the farmers. One of the most effective ways in communicating to farmers to 
improve their farming is using radio. This is a medium that has been proven to be effective in reaching out to farmers in rural areas as Ango, Illo, Yakubu, Yelwa, and Aliyu (2013) found out that radio agricultural programmes were very relevant linkage to agricultural information by majority (97.8\%) of the farmers in Nigeria. Radio can be used to improve the sharing of agricultural information to farmers in the rural area while participatory communication techniques can support agricultural extension efforts especially using local languages and rural radio to communicate directly with farmers and listeners' groups (Chapman, 2000, as quoted by Al-hassan, Andani \& Adul-Malik, 2011).

This study sought to establish the influence of radio programmes on Irish potato farming in Nakuru County. The chapter covered the background to the study, statement of the problem, purpose of the study, objectives and research questions, significance of the study, the scope, justifications, limitations and delimitations and the definition of terms.

\section{Objectives of the Study}

The objectives of this study were to:

1. Establish whether Irish potato farmers in Nakuru County listen to agricultural radio programmes;

2. Investigate the extent to which Irish potato farmers in Nakuru County apply the knowledge acquired from agricultural radio programmes in their farming;

3. Establish challenges faced by Irish potato farmers with regard to listening to radio programmes;

4. Examine whether Irish potato farming skills acquired from radio have contributed to food security in Nakuru County;

\section{Theoretical Framework}

This study was informed by two theories: Theory of Reasoned Action and Uses and Gratification Theory.

According to Argenti (2013), a number of modern communication theories can be traced back thousands of years to a single ancestor, the Greek philosopher Aristotle. In his book The Art of Rhetoric, Aristotle defined the three basic components of every speech, which have been adapted to meet the modern communication as follows: a) Speaker b) subject or message and c) person or group. This observation laid the foundation for modern communication theory as was observed by Lasswell in 1948, who added the aspect of medium and effect of the message.

Further, Shannon and Weaver (1964), created a model that showed the physical transfer of information through a transmitter. The model introduced the aspect of noise, meaning anything that interferes with the integrity of the message. Gerbner (1956) put the two models together when he emphasized the important role that perception played in communications as well as the transactional nature of communications. These models are applicable to radio communication in which a presenter in a studio sends a message through electromagnetic waves, which are received by a radio set and encoded, to the listener.

\section{The Theory of Reasoned Action}

The Theory of Reasoned Action (TRA) is one of the three classic models of persuasion, and is used in communication discourse as a theory of understanding persuasive messages. This theory was developed by Martin Fishbein and Icek Ajzen in 1967 and was derived from previous research that began as the theory of attitude. The theory aims to explain the relationship between attitudes and

behaviors within human action. TRA is used to predict how individuals will behave based on their pre-existing attitudes and behavioral intentions. An individual's decision to engage in a particular 
behavior is based on the outcomes the individual expects will come as a result of performing the behavior.

The model of TRA has been challenged by studies determined to examine its limitations and inadequacy. The major problem of TRA is pointed out to be the ignorance of the connections between individuals, both the interpersonal and social relations in which they act, and the border social structures which govern social practice. Although TRA recognizes the importance of social norms, strategies are limited to a consideration of individual perceptions of these social phenomena. Individual's belief, attitudes, and understandings constitute activity; therefore, the distinction of the two factors is ambiguous. Furthermore, social change may be generational rather than the sum of individual change. TRA fails to capture the social processes of change and the social nature of the change itself: a model in which people collectively appropriate and construct new meanings and practice.

The model focuses on analytic truth rather than synthetic one, therefore the conclusions resulting from those applications are often true by definition rather than by observation which makes the model falsifiable. The strengths of attitudes toward a behavior and subjective norms also vary cross-culturally while the process by which the behavior engaged remains the same. Under different cultures, people consider variously what other people think about their behavior, therefore the weight put on the corresponding variables vary as well. A closer examination of the cross-cultural communication process will benefit and complete the understanding of theory of reasoned action. This theory shows the relationship between farmers and radio programmes aired in Nakuru County. The farmers have the information at their disposal, however, their actions on the information are based on their attitudes and subjective norms as the theory states. The desire to use the information is informed by the potential benefit resulting to the farmer i.e., increased production, increased profit and household food security.

\section{The Uses and Gratification Theory}

Uses and Gratification Theory by Blumler and Katz (1974), on the other handle, states that the audience is active. This theory focuses on free will of audience and is deterministic as media can be used in different ways and for different purposes. The theory assumes that there is nothing as an absolute truth. The audience is said to have full control over the effect of media on them as the effect can be chosen by the audience themselves. Looking at radio programmes based on this theory, the researcher conceptualizes that farmers seek information from radio programmes to use them in improving their farming. Using this sociologically-based theory has little to no link to the benefit of psychology due to its weakness in operational definitions and weak analytical mode.

It also is focused too narrowly on the individual and neglects the social structure and place of the media in that structure. Ruggiero (2000) wrote that "most scholars agree that early research had little theoretical coherence and was primarily behaviorist and individualist in its methodological tendencies". This theory was relevant in the sense that farmers actively looked for information that they felt would improve their skills in Irish potato farming while the TRA provided all the information in which farmers chose the one they needed.

\section{Study area}

This study was carried out at Nakuru County in Kenya. Oladipo et al. (2015) defines population as members of a particular group in which the study is to be conducted. It is the totality of all units of whatever it is that you want to study, which may be human beings, other living and nonliving things (Kombo \& Tromp, 2013). This study targeted Irish potato farmers and extension officers in Nakuru County. The County comprises 11 sub-counties with a total population of 1.6 million people 866, 000 living in rural areas (KNBS, 2015) report. According to the County Department of Agriculture (2016) report, there are 219, 535 farmers in the County and 226 agricultural extension officers. 
The target population of the study was drawn from farmers and agricultural extension officers from the four purposefully sampled sub-counties namely: Kuresoi South, Naivasha, Molo and Kuresoi North. The four sub-counties have been purposefully sampled because they are the largest producers of Irish potato in the County (Nakuru County, 2016). The targeted agricultural extension officers in the four sampled sub-counties were 76 while the total number of farmers is $112,451$.

\section{Sample Size}

Gay as quoted by Mugenda and Mugenda (2009) suggested that a minimum of $10 \%$ of the accessible population is sufficient for a descriptive study while 30 cases or more are required for correlation research and experimental studies. In this regard, this being descriptive study, the researcher interviewed 15 of the 76 agricultural extension officers that represents $20 \%$ of the total number. This sample was sufficient based on the 10\% proposed by Mugenda and Mugenda (2009). The 15 agricultural extension officers were interviewed as key informants. To achieve balanced representation of the agricultural extension officers in each sub-county, the researcher interviewed at least three officers in each sub-county. The researcher has distributed the 15 officers based on the available number of officers in each sub-county as per Table 3.2. The three officers were the sub-county head of extension services, his/her deputy and one other senior officer who had at least five years' experience. In a situation where the head and deputy were of the same gender, the researcher interviewed another senior officer of different gender. In cases where the head was not available on the day of the interview, the researcher interviewed the deputy and any other senior officer of different gender from that of the deputy. In cases like that of Naivasha and Molo where five and four extension officers were sampled respectively, the head and deputy were both interviewed if they were of different genders. The other three or two officers were sampled from the other pool of senior officers who have served for at least five years in the same sub-county.

Since the number of farmers was $112,451,10 \%$ of them were 11,245 . This figure was huge for the study because of the time and resources needed. The researcher therefore interviewed farmers who were registered by the National Potato Council of Kenya in the selected sub-counties. The Council has registered 48 farmers in Kuresoi South, 51 in Molo, 42 in Kuresoi North and 39 in Naivasha totaling to 180 farmers in the sampled sub-counties. The researcher was interested in farmers who were members between 2012 and 2015. During the period, Kuresoi South had 13, Molo 21, Kuresoi North 9 and Naivasha 7 giving a total of 50 farmers. Therefore, the sample size of the primary respondents for this study was 50 farmers. Hence, the sample size for this study was 50 primary respondents and $15 \mathrm{key}$ informants giving a total of 65 respondents.

\section{RESULTS}

\section{Education of the respondents}

There were $17(35.4 \%)$ of respondents that had a secondary school certificate, followed by primary school certificate at $16(33.3 \%)$. Those with middle level college certificates represented nine (18.8\%). The lowest percentage of the respondents represented those with degrees and lower primary education both at three (6.3\%). This means that the majority of farmers $(77.7 \%)$ had a basic level of education. The middle level college or university education respondents were 25 percent. This can be implied that the higher the education, the lesser involvement in farming activities. In a similar study by Morwani et.al (2017), it was established that more farmers with post-secondary education were getting into farming due to the high rate of unemployment in Kenya.

\section{Age of the respondents}

Most farmers were between the ages of 36-45 representing 25(52.1\%) of the total respondents. The second largest percentage was that of 46-55 accounting for $213(7.1 \%)$ followed by ages 26-35 at nine 
$(18.8 \%)$ and lastly the most senior ones above 56 at one (2.1\%). This showed that the young generation as well as the senior citizens were not so much into farming. The key informants accredited that those at 56 and above in most cases have left the farms for their sons and daughters to run. In the study by Morwani, et al. (2017) conducted in Manga Sub-county, Nyamira County, it was established that the majority $(68.1 \%)$ of the farmers were male as compared to 31.9 percent who were female. The study concluded that male members of the society could dominate most farming decisions. Morwani et.al (2017) further established that most farmers were between ages 30-39 (34\%) of the respondents. This may be concluded that people below age 30 do not mostly focus on agricultural activities since they are still trying to find their career paths or are still studying. Similarly, the senior citizens (45 and above) prefer less intensive practices like small businesses as concluded by Morwani et.al, 2017.

\section{Radio listenership by respondents in the four purposively sampled sub-counties.}

It clearly displays that $46(95.8 \%)$ of the respondents listened to radio programmes. The two $(4.2 \%)$ who do not listen to radio programmes said they do not have time in the morning hours. However, they reported that they watched television mostly in the evening hours. This confirmed the observation by Ango et.al (2013) who argued that 98.7 percent of farmers in Nigeria depended on radio for agricultural information. When asked about their preferred media channel of information, the respondents hugely endorsed radio as the most preferred channel of receiving information. Radio stood at 44(87.5\%) while television came distant second with three $(10.4 \%)$. Other media included newspaper, internet and SMS that represented 2.1 percent of the respondents. The $10 \%$ who selected television preferred vernacular TV stations as medium of receiving agricultural information.

\section{Agricultural radio programmes helping in improved farming skills}

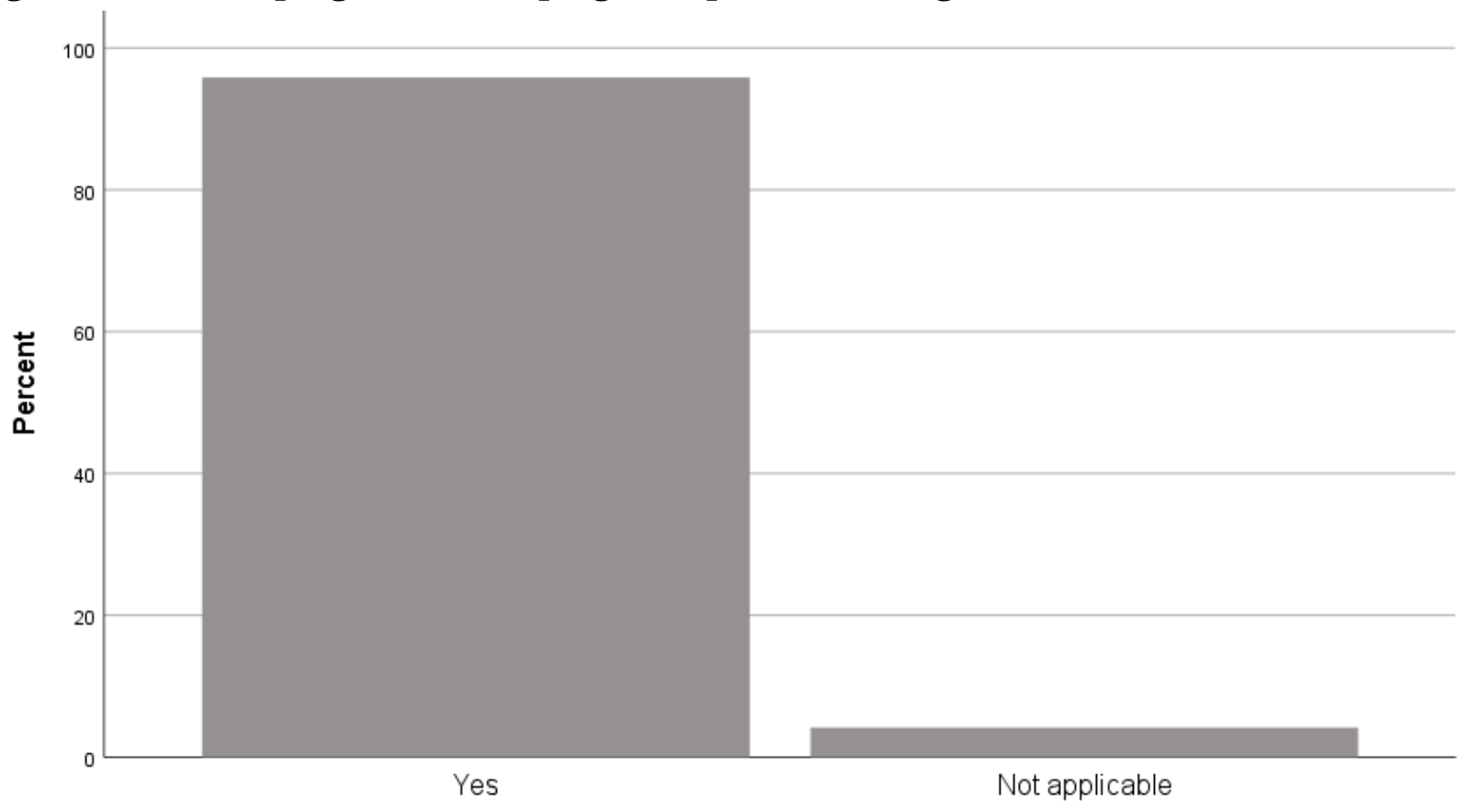

It was revealed in the study that $46(95.8 \%)$ of the respondents had been helped by radio agricultural programmes to improve Irish potato farming skills while two (4.2\%) did not know whether the programmes had been of help or not. This still demonstrated that the programmes had contributed to improved Irish potato farming skills leading to food security in Nakuru County. This implied that farmers would be able to benefit more if programmes on Irish potato farming were aired, and they 
would reap more benefits enabling them to sell surplus to other parts of the county thereby enhancing national food security.

\section{Preferred radio language}

When asked their language of preference while listening to radio programmes, $46(95.83 \%)$ of the respondents admitted that they preferred vernacular radio stations as opposed to Kiswahili and English. Two respondents (4.2\%) said they preferred the Kiswahili language while none selected English as language of preference. It was evident during the study that most of the respondents listened to Kalenjin and Kikuyu vernacular stations. This is because 90 percent of the Nakuru residents are Kikuyu and Kalenjin (KNBS, 2015).

\section{Programmes that helped improve Irish potato farming}

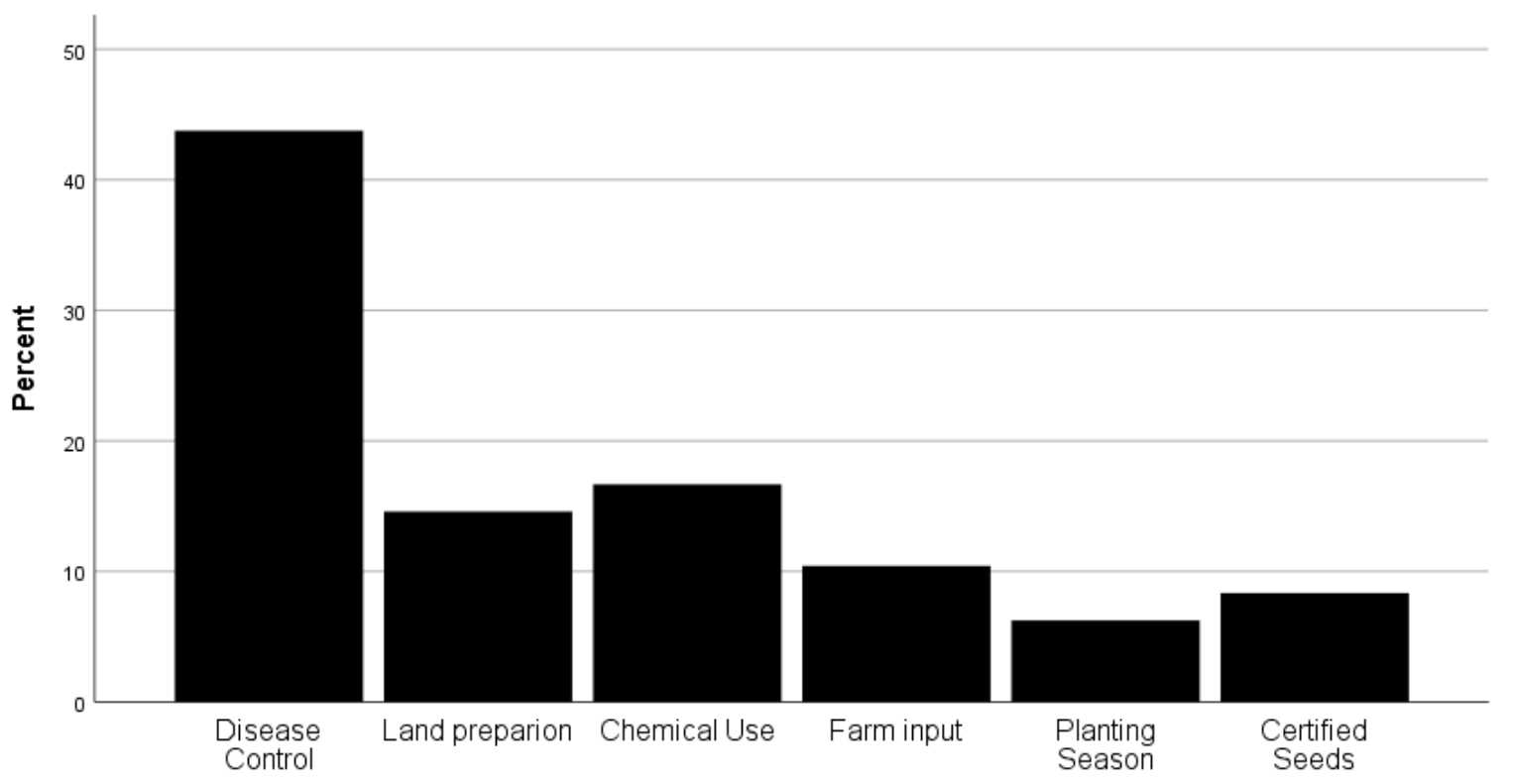

Programme that help improve Irish potato farming

The leading skill acquired that helped the farmers was disease control at 21(43.8\%) followed by chemical use at eight $(16.7 \%$ ) while land preparation and farm input came third and fourth at seven $(14.6 \%)$ and five $(10.4 \%)$ respectively. Planting season and certified seeds came last at three $(6.3 \%)$ and four $(8.3 \%)$ respectively.

\section{Information sought on radio}

Disease control showed that it is the most preferred information sought by farmers on radio at $41(28 \%)$. The second is certified seeds at 40(27\%), the third one is post-harvest storage at 24(16\%). Pesticides represented $18(12 \%)$ of the respondents while farm input and market scored five $(10 \%)$ and $14(29.2 \%)$ respectively. The least sought information is on planting season at three $(3 \%)$. According to the key informant in Kuresoi South, "respondents seemed not interested with planting season since they have mastered the patterns of rainfall and seasons and also have traditional ways of knowing when it is the season for planting particular crops". The key informant in Kuresoi South further confirmed that planting seasons have not changed; farmers still rely on March, June and August rain seasons to plant Irish potatoes 


\section{Irish potato contribution to food security in Nakuru County}

Respondents were asked whether Irish potatoes have contributed to food security in Nakuru County and the findings revealed that $41(85.4 \%)$ strongly agreed, six $(12.5 \%)$ agreed while one $(2.1 \%)$ was neutral. This implied that most farmers grow Irish potatoes for domestic consumption and sell the surplus mostly within the County. This concurred with the government's action plan on food security in which Irish potato was listed as the second food security crop after maize (GoK, 2017) report. In an Irish potato programme sponsored by the Irish Government, the PS for Agriculture said "With appropriate farming practices such as soil testing, seed cleaning, use of certified seeds, right fertilizer application regimen and mechanization, you can easily harvest 40 tonnes of potatoes per acre”, (Gichui, 2018).

\section{Acquired radio skills application into farming}

The respondents confirmed that they apply the skills they learn from radio in their Irish potato farming. The study revealed that $41(85.4 \%)$ of farmers strongly agreed that they applied the skills they acquired from radio to improve their farming while six (12.5\%) agreed and one (2.1\%) was neutral. This can be implied that radio programmes have contributed to food security in Nakuru County since the farmers and key informants concurred on the listening to the programmes and skill application on Irish potato farming. One of the key informants in Naivasha sub-county said "we have noted that the farmers have information, in most cases they are coming to us to confirm the authenticity of the information acquired from radio". In a similar study in Nigeria, Ango et al. (2013) found out that farmers adopted the new skills they learnt from radio 97.8 percent while only 2.2 percent did not adopt. This poised radio as the most effective tool for communication to farmers in rural areas.

The respondents were finally affirmed that they needed more information on Irish potato farming $45(93.8 \%)$ strongly agreeing while three $(6.3 \%)$ agreed. This showed that the farmers supported the idea of more information 100 percent. This was important feedback to the radio stations in Nakuru and Kenya at large. The key informants indicated that radio should provide more information aired at the right time when farmers are listening to radio. This would improve Irish potato farming and by reaching out to a huge number of farmers at any given time.

\section{Conclusion}

This study aimed at exploring the influence of radio programmes on Irish potato farming in Nakuru County. Thus, this study concluded that radio is still the number one channel of communication to farmers in the county. Radio is easily accessible, cheaper to buy and maintain and is a portable medium making it suitable in the rural areas as supported by FAO (2015). This poised radio as the single most preferred medium to television, newspaper and other channels.

In the conceptual framework, the study conceptualized that agricultural radio programmes were independent variables while improved Irish potato farming was dependent variable. The intervening variables were access to radio at the right time and relevance of the accessed information. The study found out that when farmers listened to these programmes they helped them improve their farming skills and this had led to improved food security in Nakuru County. Farmers however posed challenges to the framework when they disclosed that sometimes the information received is generic and sometimes irrelevant.

The study revealed that Irish potato farmers still faced challenges of certified seeds, technical support, and communication strategy as well as storage facilities. The county in conjunction with the national government could chip in to address these challenges and the crop would be able to realize its food security potential by feeding thousands of other people across the country. 
Due to the challenges mentioned above, many farmers have not been able to focus exclusively on Irish potatoes as the main farming activity. The challenges have pushed the farmers to farm in small quantities while they have capacity to do it large-scale or medium-scale. This has hindered the full potential of the crop in the County.

The study finally concluded that radio is an enabler in Irish potato farming. The more accurate the information provided, the more suitable the time, and the more relevant the information, the more the Irish potato yields making food security and nutrition a reality. The researcher discovered in the study that farmers had listened to skills on disease control, chemical use, land preparation, farm input and certified seeds. These were the major skills that the farmers revealed to have listened to and were very beneficial in improving their overall skills on Irish potato farming. If the farmers applied the skills and improvement witnessed in Irish potato farming as supported by the key informants, this meant that radio programmes had played a key role in improving food security by equipping farmers with requisite skills in increasing Irish potato production.

The study observed that communication through radio is more effective as compared to any other channel. This is because of the radio message delivery in simple customized and sometimes localized language that builds rapport between the presenter and the audience. Overtime, radio has been recognized as a catalyst in development communication and a bridge between new farming technologies and farmers. It was discovered during this study, however, that farmers were not so keen on acquiring skills on new improved varieties and certified seeds. This is a communication gap that should be bridged so that farmers can maximize the full potential in radio farming. A small percentage of farmers admitted that they could not pinpoint exactly how radio has improved their farming skills. This could emanate from language, technical information or generic information barriers. The bottom line is that agricultural radio communication should be remodeled to address these challenges.

\section{References}

Adolwa, I. S., Okoth, P. F., Mulwa, R. M., Esilaba, A., Mairura, F. S., \& Nambiro, E. (2012). Analysis of Communication and Dissemination Channels Influencing the Adoption of Integrated Soil Fertility Management in Western Kenya. Jounal of Agricultural Education and Extension, 71-86.

Africa Governance Monitoring and Advocacy Project, Open Society Initiative for Eastern Africa, and Open Society Media Program. (2011). Governance and Information Access in Africa. Nairobi: Open Society Foundations.

African Development Bank and International Food Policy Research Institute. (2014). GM Agricultural Technologies for Africa: A State of Affairs. Washington DC: IFPRI.

Al-hassan, S., Andani, A., \& Abdul-Malik, A. (2011). The Role of Community Radio in Livelihood Improvement. Journal of Field Actions.

Ango, A., Illo, A., Yakubu, A., Yelwa A, .., \& Aliyu, A. (2013). Radio Agricultural Programmes: A Means of Bridging Research Findings - Rural Farmers Gap. A Case of Zaria Metropolitan Area, Kaduna State, North Western, Nigeria. International Journal of Science and Nature, 538-545.

Argenti, P. (2013). Corporate Communication. Washington Dc: McGraw-Hill Education.

Asemah, E. (2013). Communication and the New Media in Nigeria. Lagos: African Council for Communication Education.

Bornstein, D. (2012, August 6). How to Transform African Farming: Return to "Orphan Crops". The Christian Science Monitor.

Chhachhar, A. R., Qureshi, B., Khushk, G. M., \& Ahmed, S. (2014). Impact of information and communication technologies in agriculture development. Journal of Basic and Applied Scientific Research, 281-288. 
Choudhury, P. S. (2011). Media in Development Communication. Global Media Journal-Indian Edition, $1-13$.

Devaux, A. K. (2014). Potatoes for Sustainable Global Food Security. Springer Link, 185-199.

Everett, R. (1976). Communication and Development: The Passing of the Dominant Paradigm. New York: Sage.

FAO. (2009). The State of Food Insecurity in the World 2009. Rome: FAO.

FAO. (2011). Food Security Communications Toolkit. Rome: FAO.

FAO. (2014). The State of Food and Agriculture: Innovation in family farming. Rome: FAO.

FAO, IFAD and WFP. (2015). The State of Food Insecurity in the World 2015. Meeting the 2015 International Hunger Targets: Taking Stock of Uneven Progress. Rome: FAO.

Fawole, P. (2008). Pineaple Farmers' Information Sources and Usage in Nigeria. Bulgarian Journal of Agricultural Science, 381-389.

Gichui, E. (2018, March 17th). New potato programme set to empower smallholder farmers and boost yields. Saturday Nation, p. 15.

Gildemacher, P., Demo, P., Barker, I., Kaguongo, W., Wagoire, W., \& Woldegiorgiset, A. (2009). A Description of Seed Potato Systems in Kenya, Uganda and Ethiopia. Springerlink.com.

Gildemacher, P., Demo, P., Kinyae, M., Nyongesa, M., \& Mundia, P. (2007). Selecting the Best Plants to Improve Seed Potato. LEIS A Magazine, 10-11.

Godfray, H., Beddington, J., Crute, I., Haddad, L., Lawrence, D., \& Muir, J. (2010). Food Security: The Challenge of Feeding 9 Billion People. American Association for the Advancement of Science, www.sciencemag.org.

GoK. (2011). National Food Security Policy. Nairobi: GoK.

Government of Kenya. (2017). The Big Four-Immediate Priorities and Actions. Nairobi: Government of Kenya.

Heather, E., Mark, L., Bernard, P., \& Bartholomew, S. (2017). Using radio and interactive ICTs to improve food security among smallholder farmers in Sub-Saharan Africa. Ottawa: ScienceDirect.

Hornik, R. (1988). Development Communication, Information, Agriculture and Nutrition in the Third World. New York: Longman.

Indeche, A., \& Mwaura, F. (2015). Level of knowledge on application of sustainable agriculture practices among rice farmers in Mwea, Kirinyaga County, Kenya. International Journal of Education and Research, 313-330.

International Food Policy Research Institute. (2015). 2014-2015 Global Food Policy Report. Washington DC: IFPRI.

International Potato Centre. (2014). Annual Report. Lima: CIP.

Internews. (2011). Radio Distribution Module, South Sudan. London: Internews.

Iorliam, T., Imbur, E., \& Iortima, P. (2012). Adoption of information and communication technologies as source of information on agricultural innovations among farm households in Nigeria: evidence from Benue state.

Tokyo: International Society for Development and Sustainability.

Jean-Pierre, I. (2010). Radio Broadcasting Formats Adapted to Food Security Issues. Rome: FAO.

KALRO. (2014). Irish Potato Farming Guidelines. Nairobi: KALRO.

Kanyi, J. (2017, February 10th). To ease the effects of drought, we must invest in water sources. Daily Nation, pp. 21-22.

KENFAP. (2013). A Guide to Potato Production and Post-Harvest Management in Kenya. Nairobi: KENFAB.

Khanal, S. R. (2011). Role of radio on Agricultural development: A review. Bobi: An Interdisciplinary Journal, 201-207.

Klenke, K. (2008). Qualitative Research in the Study of Leadership. Bingley: Emerald Group Publishing Limited.

Kompo, D., \& Tromp, D. (2013). Research Methods: Quantitative and Qualitative Approaches. Nairobi: ACTS Press.

Kothari, C., \& Garg, G. (2014). Research Methodology, Third Edition. New Delhi: New Age International Publishers. 
Lwoga, E. T. (2010). Bridging the agricultural knowledge and information divide: The Case of selected telecenters and rural radio in Tanzania. The Electronic Journal on Information Systems in Developing Countries, 1-14.

Mabika, M. (2014). A Tale of Failure: Indigenous Language Radio Broadcasting in Zimbabwe. Mediterranean Journal of Social Sciences, 2391-2401.

McCutcheon, R., Schaffer, J., \& Wycoff, J. (1994). Communication Matter. Minneapolis: West Publishing Company.

Melkote, S. R. (2001). Communication for Development in the Third World: Theory and Practice for Empowerment. London: Sage.

Mgbakor, M., Okezie, U. P., \& Jovita, U. N. (2013). Assessment of the Effect of Radio Listening Programme of Farmers on Agricultural Development in Enugu state,Nigeria. AmericanEurasian Journal of Agronomy, 32-39.

Ministry of Agriculture, Livestock and Fisheries. (2015). Economic Review of Agriculture. Nairobi: Central Planning and Project Monitoring Unit.

Morwani, D., Ombati, J., \& Ngesa, F. (2017). Relationship Between Level of Education of Farmers and Use of Information and Communication Technologies in Marketing of Farm Produce by Small Scale Farmers in Manga Sub-County, Kenya. International Journals of Scientific and Technology, 78-95.

Mugenda, O., \& Mugenda, A. (2009). Research Methods: Quantitative and Qualitative Approaches. Nairobi: ACTS.

Mzungu. (2013). Audience Measurement Survey. Nairobi: Synovate.

Nakuru County Department of Agriculture. (2016). Nakuru County Irish Potato Brief. Nakuru: Nakuru County Government.

National Potato Research Centre. (2014). Potato Breeding. Nairobi: KALRO.

Nazari, M. R., \& Hasbullah, A. H. (2010). Radio as an Educational Media: Impact on Agricultural Development. Journal of South East Asia REsearch Centre, 13-20.

NPCK. (2015). National Potato V ariety Catalogue. Nairobi: NPCK.

NPCK. (2016). National Potato Strategy 2016-2020. Nairobi: NPCK.

NPCK. (2016). The National Potato Strategy 2016-2020. Nairobi: Ministry of Agriculture, Livestock and Fisheries.

Odira, R. (2014). The Role of Radio Broadcasting in Enhancing Farm Production in Rural Kenya: A Case of Radio Nam Lolwe in Kakelo Location, Homa Bay County. Nairobi: University of Nairobi.

Oladipo, R., Ikamari, L., Kiplangat, J., \& Baraza, L. (2015). General Research Methods. Nairobi: Oxford University Press East Africa Limited.

Olielo, T. (2013). Food Security Problems in Various Income Groups of Kenya. African Journal of Food, Agriculture, Nutrition and Development, 6-8.

Orao, J. (2009). The Kenyan indigenous languages and the mass media: Challenges and opportunities. Stellenbosch Papers in Linguistics PLUS, 77-86.

Oriare, P. (2011). Assessing the Utility of Radio in communicating Agricultural Biotechnology, case studies of Burkina Faso and Kenya. Nairobi: OFAB.

Orodho, A. (2003). Essentials of Educational and Social Science Research Methods. Nairobi: Masola Publishers.

Paarlberg, R. (2009). Starved for Science: How biotechnology is being kept out of Africa. London: Harvard University Press.

Quebral , N. (2012). Development Communication Primer. Penang: Southbound.

Regal, B. (2005). Radio: The Life Story of a Technology. Connecticut: Greenwood Press.

Ruggiero, T. (2010). Uses and gratifications theory in the 21 st century. Mass Communication \& Society, 3-37.

Sam, J., \& Dzandu, L. (2015). The Use of Radio to Disseminate Agricultural Information to Farmers: The Ghana Agricultural Information Network System (GAINS) Experience. Agricultural Information Worldwide, Vol 7.

Sillars, S. (2009). Success in Communication. Malta: John Murray Publishers Limited. 
Simon, G. (2012). Food Security: Definition, Four Dimensions and History. Rome: University of Roma Tre. Struik, P., \& Wiersema, S. (1999). Seed Potato Technology. Wageningen: Wageningen University Press.

Trauth , E. (2001). Qualitative Research in IS: Issues and Trends. Hershey: Idea Group.

UNDP. (2015). A new sustainable development agenda. Nairobi: UNDP.

USDA. (2014). US Department of Agriculture Status Report. Washington Dc: USDA.

WFP. (2009). Hunger and Markets, World Hunger Series. London: WFP.

WHO. (2015). Health in 2015: from MDGs, Millennium Development Goals to SDGs, Sustainable Development Goals. Geneva: WHO.

World Bank. (2017). End Extreme Poverty: Boost Shared Prosperity. Washington DC: International Bank for Reconstruction and Development.

Yin, K. (2012). Applications of Case Study Research. Los Angeles: Sage Publications Inc. 